\section{Bacterial Formation of Tooeleite and Mixed Arsenic(III) or Arsenic(V)-Iron(III) Gels in the Carnoulès Acid Mine Drainage, France. A XANES, XRD, and SEM Study}

\author{
GUILLAUME MORIN, ${ }^{*} \ddagger$ FARID JUILLOT, \\ CORINNE CASIOT, $\$$ ODILE BRUNEEL, $\$$ \\ JEAN-CHRISTIAN PERSONNÉ,\$ \\ FRANCCOISE ELBAZ-POULICHET, \$ \\ MARC LEBLANC, s \\ PHILIPPE ILDEFONSE, $1,+$ AND \\ GEORGES CALAS ? \\ Laboratoire de Minéralogie Cristallographie de Paris (LMCP), \\ UMR CNRS 7590 - Universités Paris 6 et 7 - IPGP. \\ 4 Place Jussieu, 75252 Paris Cedex 05, France, and \\ Laboratoire Hydrosciences Montpellier, UMR 5569, \\ CNRS - Université Montpellier 2, Place E. Bataillon, \\ 34095 Montpellier Cedex 05, France
}

The oxidation of $\mathrm{Fe}(\mathrm{II})$ in acid mine drainage (AMD) leads to the precipitation of $\mathrm{Fe}$ (III) compounds which may incorporate toxic elements, such as arsenic (As), within their structure or adsorb them at their surface, thus limiting their mobility. The present work provides evidence for spatial and seasonal variations of microbial activity that influence arsenite oxidation and As immobilization in the heavily contaminated AMD from the Carnoulès mine, Gard, France ([As III] $=80$ to $280 \mathrm{mg} \cdot \mathrm{L}^{-1}$ in the acidic spring draining the waste-pile). In the first tens of meters of the $\mathrm{AMD}$, the rapid oxidation of $\mathrm{Fe}$ (II) leads to the coprecipitation of large amounts of As with Fe(III) in bacterial mats. XRD, XANES, and SEM analyses of sediments and stromatolite samples revealed the unusual formation of As(III)-rich compounds, especially nanocrystalline tooeleite, $\mathrm{Fe}_{6}\left(\mathrm{AsO}_{3}\right)_{4}$ $\left(\mathrm{SO}_{4}\right)(\mathrm{OH})_{4} \cdot 4 \mathrm{H}_{2} \mathrm{O}$, a rare ferric arsenite sulfate oxyhydroxide mineral, together with XRD-amorphous mixed $\mathrm{As}(\mathrm{III}) / \mathrm{As}(\mathrm{V})-\mathrm{Fe}$ (III) oxy-hydroxide compounds. In the wet season, the suspended sediments of the upstream zone essentially consist of tooeleite associated with amAs(III)-Fe(III) oxy-hydroxides, while am-As(V)-Fe(III) oxyhydroxides, having As:Fe molar ratios as high as $0.6-0.8$, dominate in the dry season. Comparing natural and bioassay samples revealed that the formation of $\mathrm{As}$ (III)rich compounds in the wet season may be related to the metabolic activity of bacterial strains able to oxidize Fe(II) but not $\mathrm{As}$ (III). One of these strains, having an Acidithiobacillus

* Corresponding author phone: 331442775 04; fax: 3314427 37 85; e-mail: Guillaume.Morin@Imcp.jussieu.fr. Corresponding author address: LMCP, case 115, 4 Place Jussieu, 75252 Paris Cedex 05, France.

${ }^{\dagger}$ Deceased October 26, 1999.

${ }^{\ddagger}$ Universités Paris 6 et 7 - IPGP.

${ }^{5}$ CNRS - Université Montpellier 2. ferrooxidans genotype, has been isolated from the Carnoulès AMD. In contrast, the formation of $\mathrm{As}(\mathrm{V})$-rich compounds in the dry season can be related to both biotic and abiotic oxidation of $\mathrm{As}(\mathrm{III})$ to $\mathrm{As}(\mathrm{V})$. Some Thiomonas strains isolated from the Carnoulès AMD were shown to be able to catalyze the oxidation of $\mathrm{As}(\mathrm{III})$ to $\mathrm{As}(\mathrm{V})$ in solution. Therefore, they can promote the formation of mixed As(V)-Fe(III) oxy-hydroxides, provided enough Fe(II) oxidizes. These results yield a better understanding of natural processes at this site and may help in designing efficient As-removal processes.

\section{Introduction}

The oxidation of $\mathrm{Fe}$ (II) to $\mathrm{Fe}(\mathrm{III})$, often catalyzed by the metabolic activity of microorganisms such as Acidithiobacillus ferrooxidans $(1,2)$, leads to the precipitation of more or less ordered iron oxy-hydroxides $(2,3)$, that are able to incorporate toxic elements within their structure or adsorb them at their surface $(4,5)$. Such reactions may strongly limit the mobility of As in various environments including acid mine drainage (AMD) $(6-8)$, hot-springs $(9,10)$, and soils (11).

In AMD, microbial Fe(II) to Fe(III) oxidation and progressive neutralization of acid waters frequently leads to the precipitation of $\mathrm{Fe}$ sulfates and oxy-hydroxides within the sequence jarosite $\mathrm{KFe}_{3}\left(\mathrm{SO}_{4}\right)_{2}(\mathrm{OH})_{6}$, schwertmannite $\mathrm{Fe}_{8} \mathrm{O}_{8}$ $(\mathrm{OH})_{6} \mathrm{SO}_{4}$, ferrihydrite $\mathrm{Fe}_{5}(\mathrm{OH})_{8} \cdot 4 \mathrm{H}_{2} \mathrm{O}$, goethite $\alpha-\mathrm{FeOOH}$, or lepidocrocite $\gamma$-FeOOH, as a function of rising $\mathrm{pH}(1,12)$. Arsenic is scavenged by structural incorporation in some of these minerals $(13-15)$ and by adsorption onto their surface (15). In some hot springs $(16-18)$ and AMD (19), specific bacterial strains also catalyze the oxidation of dissolved arsenite. When As:Fe ratios are high enough in AMD, neoformed mixed As-Fe oxy-hydroxides exhibit As:Fe molar ratios as high as $0.7-1.0(14)$.

The present work is aimed at assessing the influence of microorganisms on the oxidation and scavenging of As from AMD at the Carnoulès mine, which exhibits exceptionally high arsenite levels $(6,21,22)$.

\section{Materials}

Site Description. The Carnoulès $\mathrm{Pb}-\mathrm{Zn}-\mathrm{Sb}$ mine is located in the southeastern border of the Massif-central, Gard, France, in the drainage basin of the Gardon river, which is a tributary of the Rhône river. The mining activity that stopped in 1962 at this site, resulted in about $1.5 \mathrm{Mt}$ of sulfur mine wastes containing $0.7 \% \mathrm{~Pb}, 10 \% \mathrm{Fe}$, and $0.2 \% \mathrm{As}(6)$, which are stored behind a $6 \mathrm{~m}$ high dam in the upper part of the Reigous valley. The acidic Reigous spring ( $\mathrm{pH} 2.5-4)$ that emerges at the bottom of the dam collects meteoric waters percolating through the tailing and yields the Carnoulès AMD. Due to dilution effects, dissolved As concentration (80 to $\left.350 \mathrm{mg} \cdot \mathrm{L}^{-1}\right)$ in the AMD is anticorrelated to the flow rate of the spring $(0.2-1.3 \mathrm{~L} / \mathrm{s})$, which varies as a function of meteoric conditions $(6,21,22)$. The mean annual rainfall is $1100 \mathrm{~mm}$ with a seasonal distribution typical of the Mediterranean climate characterized by long drought periods in summer and intense precipitation events, especially in spring and fall. In the first tens of meters of the AMD (Figure 1), large amounts of $\mathrm{Fe}$ and As precipitate from solution and accumulate in yellow to orange bacterial mats covering the bed of the creek and containing up to $20 \mathrm{~mol} \%$ As (6). 


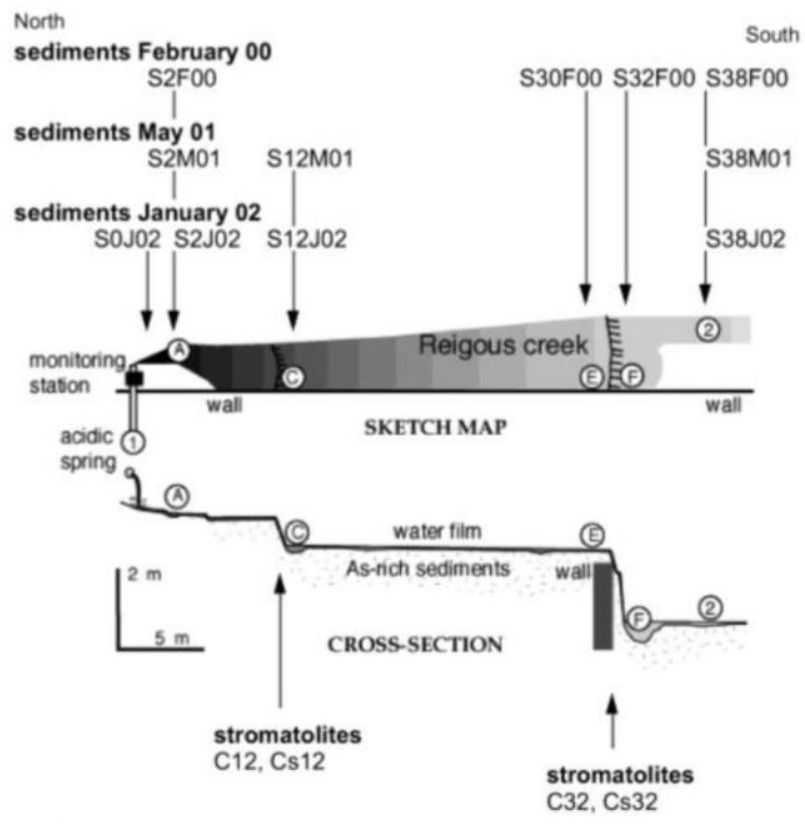

FIGURE 1. Sketch map of the site studied, referred to as "the Carnoulès AMD", which corresponds to the first $40 \mathrm{~m}$ of the Reigous Creek draining the Carnoulès mine waste pile. An overhead view and a cross-section of the site studied are displayed in the same scale at the top and the bottom of the figure, respectively. Sediment samples were collected at $0 \mathrm{~m}$ (S0J02), $2 \mathrm{~m}$ (S2F00, S2M01, S2J02), $12 \mathrm{~m}$ (S12M01, S12J02), $30 \mathrm{~m}$ (S30F00), $32 \mathrm{~m}$ (S32F00), and $38 \mathrm{~m}$ (S38F00, S38M01, S38J02) downstream from the acidic spring. Stromatolite sampling points are indicated below.

Field Samples. Oxidation state and structural environment of As were studied in a set of 15 solid samples collected along the first $40 \mathrm{~m}$ of the Carnoulès AMD, in February 2000 , May 2001, and January 2002 (Figure 1). January and February, on one hand, and May, on the other hand, correspond to the wet season and the beginning of the dry season, respectively (21).

Suspended sediments collected by brief sedimentation of very turbid water samples ([solid] $>10 \mathrm{~g} / \mathrm{L}$ ) are referred to as S2F00, S30F00, S32F00, S38F00 (February 2000 samples), S2M01, S12M01, S38M01 (May 2001 samples), and S0J02, S2J02, S12J02, S38J02 (January 2002 samples). The numbers between 2 and 38 correspond to the sampling points which ranged from 2 to $38 \mathrm{~m}$ beyond the spring, as reported in Figure 1. These sediment samples exhibit pale yellow to orange color and consist of very fine powder after air-drying (aggregates of few microns in diameter at maximum).

Stromatolite samples were also collected from bacterial accretions covering concrete walls of a few $\mathrm{dm}$ to $2 \mathrm{~m}$ height in the bed of the Carnoulès AMD (Figure 1; Table 1). A detailed description of the layered structure of Carnoulès stromatolites is given in ref 6 . Each stromatolite consists of a stacked structure where crusty brown layers of a few millimeters thickness alternate with centimeter-thick layers of loosely packed yellow powder, that were separated by hand, and are referred to as C and Cs, respectively. Two distinct stromatolites were sampled, at 12 and $32 \mathrm{~m}$ distance from the spring (see Figure 1). Major and minor dissolved species as well as As and Fe oxidation-state were also measured in corresponding water samples after $0.45 \mu \mathrm{m}$ filtration (see the Water Analyses section).

Bioassays. Six distinct bacterial strains were isolated from Carnoulès AMD water samples after $5-10$ purification steps consisting of serial streaking of single colonies on agar media. Two media were used, the R2A or 100:10 media, the first being specific for organoheterotrophic bacteria (23) and the latter being specific for lithotrophic bacteria such as Acidithio- bacillus ferroxidans (24). Bacterial strains B1, B2, and B3, on one hand, and B4, B5, and B6, on the other hand, were isolated from the R2A medium and the 100:10 medium, respectively. Phylogenetic identifications performed after PCR amplification of sequences of $16 \mathrm{~S}$ rDNA (encoding $16 \mathrm{~S}$ rRNA) indicated that the B1, B2, and B3 strains have a Thiomonas genotype and that the B4 and B5 strains have an Acidithiobacillus ferrooxidans genotype. The B6 population was not clearly identified.

$\mathrm{Fe}$-As hydrous precipitates were then prepared at the laboratory by inoculating sterilized water from the Carnoulès AMD spring with the autochthonous bacterial strains (B1-B6) described above. For that purpose, a few liters of water from the Carnoulès AMD spring sampled in June 2001 were sterilized by $0.45 \mu \mathrm{m}$ filtration and were split into 250 $\mathrm{mL}$ aliquots. Each aliquot was then inoculated with one of the selected bacterial strains (B1-B6) except one blank sample (SA) that was not inoculated. Solutions were then aged for $150 \mathrm{~h}$ while stirring in contact with air. At the end of all experiments, precipitated solids were decanted and then air-dried for $48 \mathrm{~h}$. Major elements in the solids were analyzed by inductively coupled plasma (ICP) after acid dissolution or by electron microprobe analysis (EMPA) of small pellets. Total As and Fe concentrations as well as As and $\mathrm{Fe}$ oxidation-state were measured in the supernatant after $0.45 \mu \mathrm{m}$ filtration (see the Water Analyses section).

Model Compounds. A tooeleite sample from Tooele County, UT (25) kindly furnished by Pr. F. Cesbron was used as a model compound for powder X-ray Diffraction (XRD) and X-ray absorption near-edge spectroscopy (XANES). Approximately $50 \mathrm{mg}$ of almost pure tooeleite from this sample was carefully hand picked under a binocular lens. Less than $1 \%$ scorodite impurity was present in the sample.

Two XRD-amorphous mixed As-Fe oxy-hydroxides with $\mathrm{As}(\mathrm{V})-\mathrm{Fe}$ (III) and As(III)-Fe(III) compositions were synthesized and are referred to as cpp5 and cpp3, respectively. $\mathrm{A} \mathrm{Na}_{2} \mathrm{HAsO}_{4} \cdot 7 \mathrm{H}_{2} \mathrm{O}(0.3 \mathrm{M})+\mathrm{Fe}\left(\mathrm{NO}_{3}\right)_{3} \cdot 9 \mathrm{H}_{2} \mathrm{O}(0.6 \mathrm{M})$ solution and a $\mathrm{NaAsO}_{2}(0.3 \mathrm{M})+\mathrm{Fe}\left(\mathrm{NO}_{3}\right)_{3} \cdot 9 \mathrm{H}_{2} \mathrm{O}(0.6 \mathrm{M})$ solution, respectively, were neutralized to $\mathrm{pH} 7$ by adding appropriate volumes of a $\mathrm{NaOH} 1 \mathrm{M}$ solution. Solids were air-dried after centrifugation. They exhibit As:Fe ratios of 0.39 and 0.32 , respectively (Table 1 ).

These three samples were used as model compounds for XANES data fitting. Our As K-XANES spectra set also included crystalline scorodite $\left(\mathrm{FeAsO}_{4} \cdot 2 \mathrm{H}_{2} \mathrm{O}\right)$, pharmacosiderite $\left(\mathrm{KFe}_{4}\right.$ $\left.\left(\mathrm{AsO}_{4}\right)_{3}(\mathrm{OH})_{4} \cdot 6-7 \mathrm{H}_{2} \mathrm{O}\right)$, beudantite $\left(\mathrm{PbFe}_{3}\left(\mathrm{AsO}_{4}\right)\left(\mathrm{SO}_{4}\right)(\mathrm{OH})_{6}\right)$, parasymplesite $\left(\mathrm{Fe}_{3}\left(\mathrm{AsO}_{4}\right)_{2} \cdot 8 \mathrm{H}_{2} \mathrm{O}\right)$, and arsenolite $\left(\mathrm{As}_{2} \mathrm{O}_{3}\right)$, but none of these latter minerals was recognized in the investigated samples either by XRD or by XANES.

\section{Experimental Methods}

Solid Samples Characterization. Crystalline phases where identified using $\mathrm{X}$-ray powder diffraction (XRD). Data were collected with a PHILIPS PW1710 diffractometer using $\mathrm{Co}-\mathrm{K} \alpha$ radiation at $40 \mathrm{kV}$ and $30 \mathrm{~mA}$ in step scan mode between 3 and $120^{\circ} 2 \theta$ with a $0.04^{\circ} 2 \theta$ step and a counting time of 8-25 s per step. Samples were loaded on hollowed aluminum plates. Instrumental fwhm was $\Delta 2 \theta=0.08^{\circ}$ at $0^{\circ}$ (Figures 2 and 3). The powder pattern of the Utah tooeleite was recorded for $3 \mathrm{~h}$ in transmission Debye-Scherrer geometry at the DW22 wiggler-beamline at LURE, Orsay, France. The sample was mounted in a silica capillary of 500 $\mu \mathrm{m}$ in diameter. The wavelength was $0.6926 \AA$, and the instrumental fwhm was $\Delta 2 \theta=0.03^{\circ}$ at $0^{\circ}$ (Figure 2).

Bulk chemical compositions of powder samples were determined by EMPA using a SX50 CAMECA microprobe equipped with four wavelength dispersion spectrometers (WDS) operating at $20 \mathrm{kV}$ and $40 \mathrm{nA}$ and counting $10 \mathrm{~s}$ per element. To obtain bulk composition, samples were prepared as pellets of approximately $1 \mathrm{~mm}$ in thickness, and 20 analyses 
TABLE 1. Chemical Composition of the Samples Studied (in wt \%) and Corresponding As Speciation: Sediments (Sed), Stromatolites, Abiotic (SA), Thiomonas (Tm), Acidithiobacillus ferrooxidans (Af) ${ }^{a}$

\begin{tabular}{|c|c|c|c|c|c|c|c|c|c|c|c|c|}
\hline \multirow[b]{2}{*}{ sample } & \multicolumn{7}{|c|}{ chemical composition } & \multicolumn{5}{|c|}{ As-bearing phases ( $\%$ of total As) } \\
\hline & $\mathrm{As}_{2} \mathrm{O}_{5}$ & $\mathrm{As}_{2} \mathrm{O}_{3}$ & $\mathrm{Fe}_{2} \mathrm{O}_{3}$ & $\mathrm{SO}_{3}$ & total & $\mathrm{As} / \mathrm{Fe}$ & $\overline{\mathrm{As}(\mathrm{III}) / \mathbf{\Sigma} \mathrm{As}}$ & cpp5 & сpp3 & tooel & total & $\chi^{2}$ \\
\hline \multicolumn{13}{|c|}{ Feb 00 Sed } \\
\hline S2F00 & 0.0 & 25.5 & 43.5 & 7.9 & 77.5 & 0.47 & 1.00 & 0 & 55 & 43 & 98 & 1.4 \\
\hline S30F00 & 13.5 & 16.0 & 39.5 & 5.2 & 75.6 & 0.57 & 0.58 & 42 & 19 & 39 & 101 & 3.1 \\
\hline $\mathrm{S} 32 \mathrm{~F} 00$ & 31.1 & 2.0 & 37.2 & 3.3 & 75.9 & 0.62 & 0.07 & 94 & 7 & 0 & 101 & 3.3 \\
\hline S38F00 & 28.8 & 1.3 & 38.5 & 9.0 & 78.4 & 0.55 & 0.05 & 94 & 5 & 0 & 100 & 4.5 \\
\hline \multicolumn{13}{|c|}{ May 01 Sed } \\
\hline $\mathrm{S} 2 \mathrm{M} 01^{*}$ & 39.3 & 1.1 & 39.1 & 1.3 & nd & 0.72 & 0.03 & 96 & 3 & 0 & 99 & 1.1 \\
\hline $\mathrm{S} 12 \mathrm{M} 01^{*}$ & 26.2 & 3.1 & 31.7 & 7.8 & nd & 0.65 & 0.12 & 88 & 12 & 0 & 100 & 0.9 \\
\hline $\mathrm{S} 38 \mathrm{M} 01^{*}$ & 25.8 & 2.7 & 32.7 & 4.4 & nd & 0.62 & 0.11 & 89 & 11 & 0 & 100 & 1.0 \\
\hline \multicolumn{13}{|c|}{ Jan 02 Sed } \\
\hline SOJ02 & nd & nd & nd & nd & nd & nd & 0.95 & 5 & 42 & 52 & 99 & 1.9 \\
\hline $\mathrm{S} 2 \mathrm{~J} 02$ & nd & nd & nd & nd & nd & nd & 0.80 & 19 & 33 & 47 & 99 & 1.7 \\
\hline S12J02 & nd & nd & nd & nd & nd & nd & 0.91 & 9 & 34 & 55 & 98 & 1.6 \\
\hline S38J02 & nd & nd & nd & nd & nd & nd & 0.40 & 57 & 20 & 20 & 97 & 4.1 \\
\hline \multicolumn{13}{|c|}{ Stromatolites } \\
\hline C12 & 0.0 & 25.8 & 49.2 & 5.3 & 81.3 & 0.42 & 1.00 & 0 & 78 & 21 & 99 & 1.1 \\
\hline Cs12 & 10.5 & 23.2 & 43.0 & 3.7 & 81.2 & 0.61 & 0.72 & 31 & 31 & 41 & 103 & 1.7 \\
\hline C32 & nd & nd & nd & nd & nd & nd & 0.77 & 26 & 24 & 52 & 102 & 0.9 \\
\hline $\operatorname{Cs} 32^{\prime \prime}$ & 15.6 & 15.1 & 49.4 & 9.1 & nd & 0.47 & 0.53 & 47 & 6 & 48 & 100 & 0.9 \\
\hline \multicolumn{13}{|c|}{ Bioassays } \\
\hline SA & 37.0 & 0.0 & 35.7 & 6.4 & 80.6 & 0.72 & 0.00 & 99 & 0 & 0 & 99 & 4.8 \\
\hline B1 (Tm) & 30.1 & 0.0 & 37.4 & 8.2 & 79.3 & 0.56 & 0.00 & 100 & 0 & 0 & 100 & 3.4 \\
\hline B2 (Tm) & 35.1 & 0.0 & 38.8 & 7.0 & 81.8 & 0.64 & 0.00 & 100 & 0 & 0 & 100 & 2.1 \\
\hline B3 (Tm) & 40.4 & 0.0 & 35.2 & 4.4 & 82.4 & 0.80 & 0.00 & 99 & 0 & 0 & 99 & 8.1 \\
\hline B6 (n.d.) & 38.3 & 0.7 & 33.9 & 3.1 & 76.9 & 0.80 & 0.02 & 98 & 2 & 0 & 100 & 1.8 \\
\hline B4 (Af) & 26.2 & 2.5 & 41.0 & 8.0 & 81.6 & 0.49 & 0.10 & 89 & 10 & 0 & 99 & 3.8 \\
\hline B5 (Af) & 4.8 & 16.6 & 45.1 & 11.7 & 78.9 & 0.37 & 0.80 & 20 & 37 & 43 & 99 & 2.3 \\
\hline \multicolumn{13}{|c|}{ Model Compounds } \\
\hline synthetic cpp5 & 30.0 & 0.0 & 53.0 & 0.00 & 83.0 & 0.39 & 0.00 & 100 & 0 & 0 & 100 & 0.0 \\
\hline synthetic срр3 & 0.0 & 24.0 & 60.0 & 0.00 & 84.0 & 0.32 & 1.00 & 0 & 100 & 0 & 100 & 0.0 \\
\hline tooeleite (Utah) & 0.0 & 33.2 & 43.6 & 7.3 & 84.1 & 0.62 & 1.00 & 0 & 0 & 100 & 100 & 0.0 \\
\hline
\end{tabular}

were recorded for each sample using an unfocused electron beam (approximately $10 \mu \mathrm{m}$ in diameter). Some samples were analyzed for As and Fe by ICP after dissolution in $\mathrm{HNO}_{3}(14.5$ M). (Table 1).

Microscopic observations were conducted with a LEICA Stereoscan 440 Scanning Electron Microscope (SEM) equipped with an Energy Dispersive Spectrometer (EDS) for chemical analyses $(20 \mathrm{kV}, 150 \mathrm{pA})$.

XANES Spectroscopy. Arsenic oxidation-state was measured by XANES in bioassay samples as well as in sediment and bacterial accretion (stromatolite) samples collected along the Carnoulès AMD. Data were recorded at the As K-edge $(11859 \mathrm{eV})$ at room temperature in transmission mode on the D44 bending-magnet beamline at the Laboratoire pour I'Utilisation du Rayonnement électromagnétque (LURE, Orsay, France). A Si(511) double-crystal monochromator yielded an energy resolution of approximately $0.3 \mathrm{eV}$. Energy was calibrated by using a double-transmission setup in which the As K-edge spectrum of the samples and the Au K-edge spectrum of an Au foil were simultaneously recorded. The first absorbance maximum of the Au edge at $11947 \mathrm{eV}$ was used as a reference energy point. Summing three scans for each sample yielded good signal/noise ratios, due to high As concentrations in the samples (17-26 mol \% As; Table 1).

Proportions of three relevant model compounds, namely Utah tooeleite, cpp5, and cpp3 (see the Materials section), were determined in all field and laboratory samples by linearleast-squares fitting of their XANES spectra (see examples in
Figure 4). Owing to the similar position of the white-line in the tooeleite and cpp3 XANES spectra, accuracy on the relative proportions of these two components is estimated to $\pm 30 \%$. Despite this uncertainty, tooeleite was identified thanks to the presence of two bands at 11881 and $11898 \mathrm{eV}$, which are quasi-absent in the XANES spectrum of cpp3 (Figure 4). Absolute accuracy on the As(III)/ $\Sigma$ As ratio was $\pm 2 \%$, as determined by fitting of synthetic mixtures of cpp3 and cpp5 (data not shown). According to this calibration procedure, components lower than $5 \%$ were not significant.

Water Analyses. Water samples were collected along the Carnoulès AMD, at sampling points 1, A, C, E, F and 2 (Figure 1), during monthly sampling campaigns carried out in years 2001 and 2002. Water chemistry data from May 2001 and January 2002 for which solid samples were collected simultaneously are reported in Table 3, Supporting Information. Water chemistry data from February 2001 are also reported. The $\mathrm{pH}$ and dissolved $\mathrm{O}_{2}$ were measured in the field. $\mathrm{pH}$ was measured with an Ultrameter Model 6P (Myron L Company, Camlab, Cambridge) equipped with a $\mathrm{pH}$ sensor. Dissolved $\mathrm{O}_{2}$ was measured with CHEMets tests based on colorimetric detection after reaction of $\mathrm{O}_{2}$ with indigo carmine. Water samples were filtered immediately after sampling through $0.45 \mu \mathrm{m}$ Millipore membranes and were acidified to $\mathrm{pH} 1$ with $\mathrm{HNO}_{3}(14.5 \mathrm{M})$ and stored at $4{ }^{\circ} \mathrm{C}$ in polyethylene bottles until analysis. Total dissolved Fe was determined by Flame Atomic Absorption Spectrometry. Total dissolved As was 


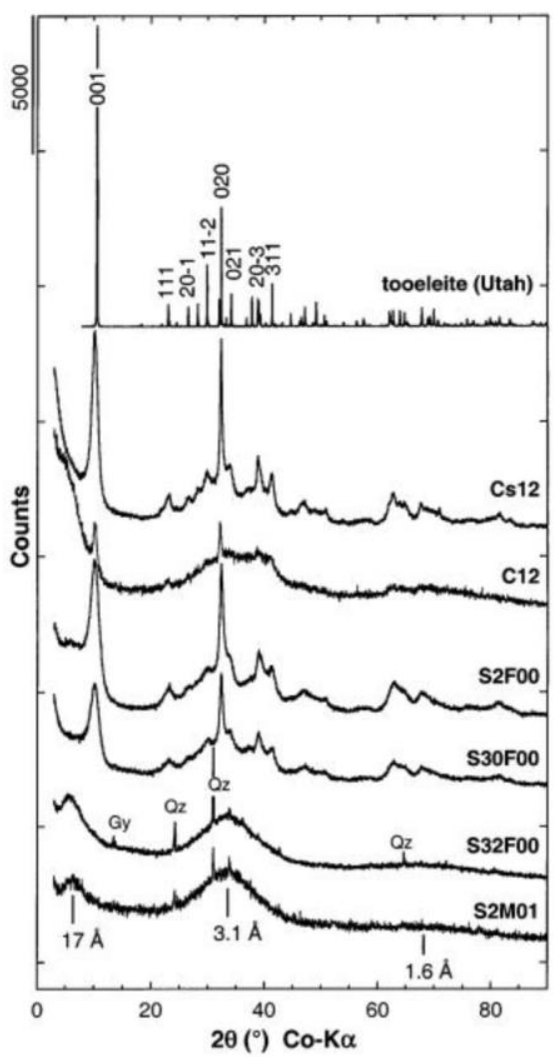

FIGURE 2. XRD powder patterns of representative field samples. Top: As(III)-rich stromatolite samples (C12 and Cs12); Center: As(III)-rich to $\mathrm{As}(\mathrm{V})$-rich sediments sampled in February (S2F00, S30F00 and S32F00); Bottom: As(V)-rich sediment sampled in May (S2M01). Part of the XRD pattern of the Utah tooeleite is indexed with a monoclinic unit cell at the top of the figure.

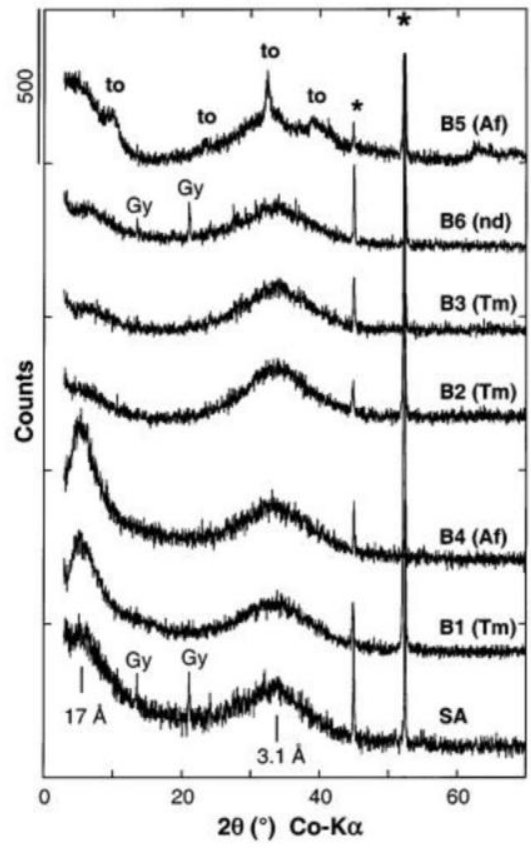

FIGURE 3. XRD patterns of the bioassay precipitates. Abiotic (SA), Thiomonas (Tm), Acidithiobacillus ferrooxidans (Af), undetermined phyllum (n.d.); to: tooeleite; ${ }^{\star}$ : aluminum sample-holder.

measured by Inductively Coupled Plasma-Mass Spectrometry (ICP-MS) after 1:1000 dilution. Fe and As speciation as well as sulfate determination were carried out within $24 \mathrm{~h}$ after sampling on nonacidified filtered samples. Total dissolved

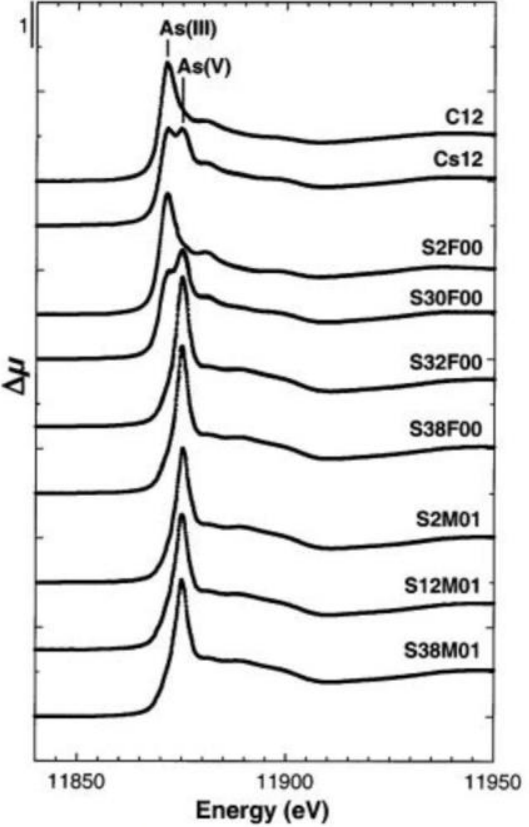

FIGURE 4. As K-edge XANES spectra of representative field samples. Top: stromatolite samples (C12 and Cs12); Center: sediments sampled in February (S2F00, S30F00, S32F00, and S38F00); Bottom: sediments sampled in May (S2F00, S30F00, S38F00). Dots: experimental; Plain line: linear least-squares fit. The fitted curves perfectly match the experimental ones.

sulfate was determined by nephelometry after precipitation of $\mathrm{BaSO}_{4}$ with $\mathrm{BaCl}_{2}$ (26). Dissolved As(III) was determined following the method by (27) using a hydride generation system coupled to the ICP-MS. The detection limit was 75 $\mathrm{ng} / \mathrm{L}$, and the precision was $5 \%$. Dissolved $\mathrm{Fe}$ (II) was measured by colorimetry at $510 \mathrm{~nm}$ after phenanthroline complexation (26). The detection limit was $0.01 \mathrm{mg} / \mathrm{L}$, and the precision was $5 \%$. Water samples from bioassay experiments were analyzed with the same methods.

\section{Results}

Crystal-Chemistry of the Solids. All samples studied, including the suspended sediments, stromatolite and bioassay samples, exhibit similar chemical compositions; however, As:Fe molar ratios are systematically higher in the pure As(V)-samples (As:Fe $=0.55-0.8$ ) than in As(III)-pure samples $(\mathrm{As}: \mathrm{Fe}=0.4-0.5)($ Table 1). They consist of mixed $\mathrm{Fe}-\mathrm{As}-\mathrm{S}$ hydrous oxides containing $26-34$ wt $\% \mathrm{Fe}, 19-24$ wt $\%$ As, and $1-3 \mathrm{wt} \% \mathrm{~S}$ with other elements being in minor or trace amounts, as determined by EMPA. According to the total values from EMPA, the $\mathrm{H}_{2} \mathrm{O}$ content may range between 18 and $25 \mathrm{wt} \%$. As detailed in the following text, XRD, XANES, and SEM data indicate that As occurs in three distinct mineral forms in the field and laboratory samples studied (Table 1): (i) XRD-amorphous mixed As(V)-Fe(III) oxy-hydroxide, referred to as "am-As(V)Fe(III)-Ox"; (ii) XRD-amorphous mixed $\mathrm{As}$ (III)-Fe(III) oxy-hydroxide, referred to as "am-As(III)Fe(III)$\mathrm{Ox}$ "; and (iii) nanocrystalline tooeleite, $\mathrm{Fe}_{6}\left(\mathrm{AsO}_{3}\right)_{4}\left(\mathrm{SO}_{4}\right)(\mathrm{OH})_{4}$. $4 \mathrm{H}_{2} \mathrm{O}$.

Proportions of these species in field and laboratory samples were determined by least-squares fitting of XANES spectra (Figures 4 and 5, respectively). Some examples of this fitting procedure are given in Figure 6. Results for all samples are summarized in Figure 7 and detailed in Table 1. Among all samples studied, As(V)-rich samples were essentially XRD-amorphous, while As(III)-rich ones consisted of a mixture of nanocrystalline tooeleite and of XRD-amorphous material. 


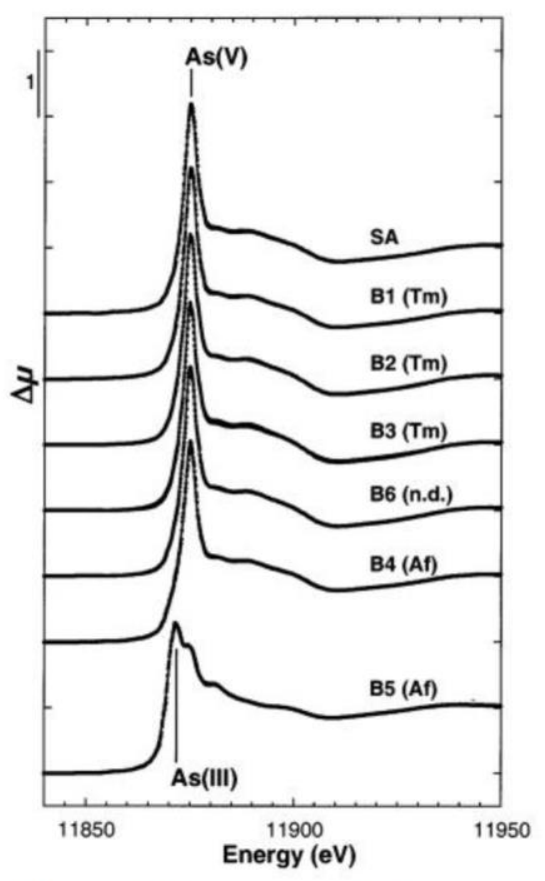

FIGURE 5. As K-edge XANES spectra of the bioassay precipitates. Abiotic (SA), Thiomonas (Tm), Acidithiobacillus ferrooxidans (Af), undetermined phyllum (n.d.). Dots: experimental; Plain line: linear least-squares fit. The fitted curves perfectly match the experimental ones.

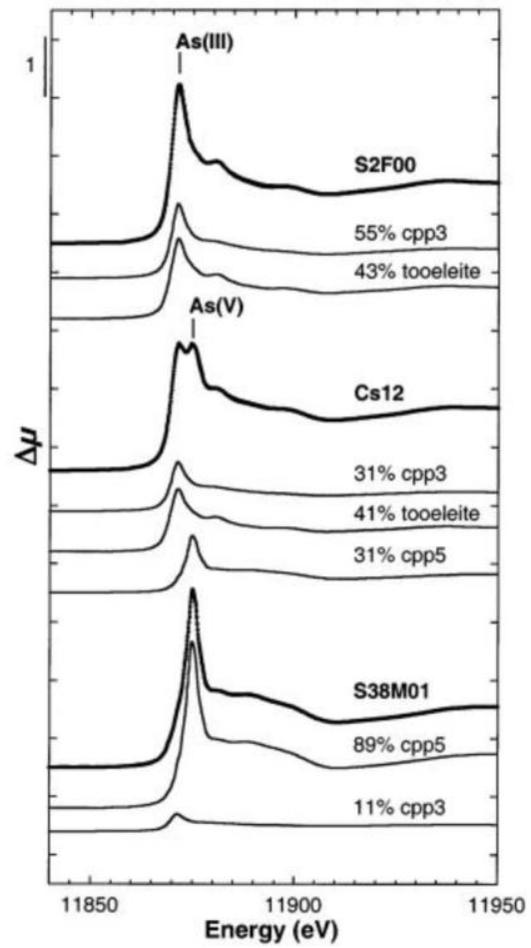

FIGURE 6. Linear least-squares fit of XANES spectra of contrasted field samples, using three model components (срp3, tooeleite and cpp5; see text); Dots: experimental; Plain line: linear least-squares fit. The fitted curves perfectly match the experimental ones. Weighted spectra of the fitting components are reported in plain lines below each fitted spectrum.

As(III) Samples. Upstream sediments collected in February 2000 (S2F00, S30F00) and all sediments collected in January 2002 (S0J02, S2J02, S12J02, S38J02) as well as most of the stromatolite samples (Cs12, C32, Cs32) contain large amounts

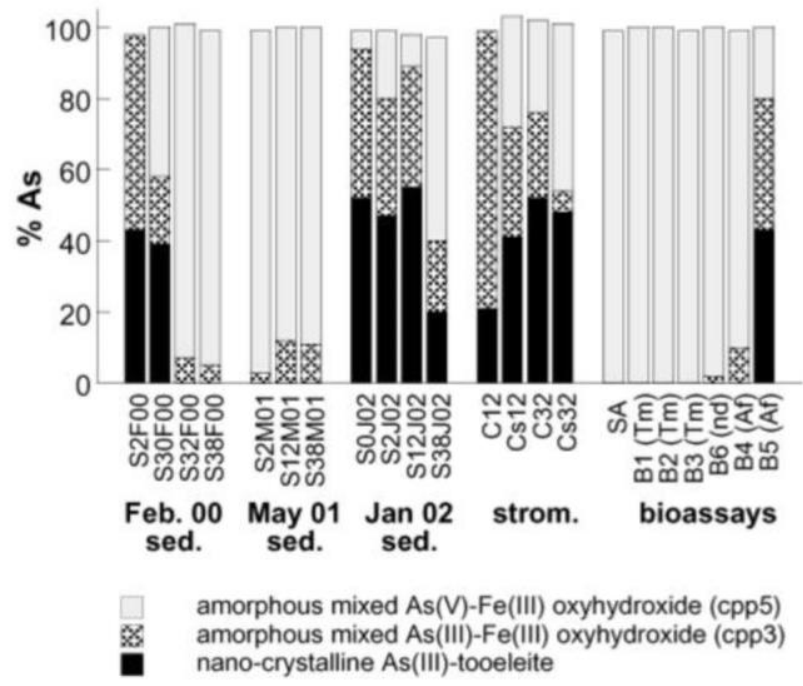

FIGURE 7. Oxidation state of As and As speciation in the samples studied. Corresponding chemical compositions are reported in Table 1.

of a finely divided crystalline phase with an XRD pattern similar to that of tooeleite (Figure 2). XANES data indicated all these samples are dominated by As(III) (Figures 3 and 7, Table 1). Among bioassay samples, only sample B5 contains tooeleite (Figure 3). Although tooeleite was previously described as an iron arsenate sulfate oxy-hydroxide (25), it is actually an iron arsenite sulfate oxy-hydroxide mineral with approximate structural formula $\mathrm{Fe}_{6}\left(\mathrm{AsO}_{3}\right)_{4}\left(\mathrm{SO}_{4}\right)(\mathrm{OH})_{4}$. $4 \mathrm{H}_{2} \mathrm{O}$. Indeed, XANES spectroscopy indicates that As occurs only as As(III) in the Utah tooeleite (Figure 6). At Carnoulès, tooeleite has a very small crystallite size $(8-9 \mathrm{~nm})$ as indicated by Bragg peak broadening, using the Scherrer formula (28), and is always associated with XRD-amorphous material (Figure 2). The presence of this amorphous phase may explain why tooeleite-rich samples from Carnoulès have smaller As: Fe ratios than the Utah tooeleite (As: $\mathrm{Fe}=0.40-0.50$ and 0.62 , respectively). In the XRD pattern of the nanocrystalline tooeleite from Carnoulès, the position of the broad [001] Bragg reflection is shifted toward lower $2 \theta$ angles, compared to that of the well-crystallized Utah tooeleite (i.e., $10.09^{\circ}$ and $10.56^{\circ}$, respectively). This peak-shift is related to the nanometric size of the crystallites, which spreads the scattered intensity around the Bragg position. At small Bragg angle, the rapid increase of the atomic scattering factor toward lower $2 \theta$ values leads to an asymmetric broadening of the peak, causing a shift of its maximum position (28). Small amounts of gypsum and quartz are also present in some samples, but no other crystalline As or Fe bearing phases than tooeleite could be identified by XRD in any sample studied (Figures 2 and 3). SEM observations of tooeleite-bearing samples show the presence of reticulated, layered structures that can be related to nanocrystalline tooeleite (B5, C12, and $\mathrm{S} 2 \mathrm{~J} 02$ in Figure 8). Indeed, these structures are particularly abundant in tooeleite samples ( $\geq 40 \mathrm{wt} \%$ tooeleite) having bright yellow or orange color, i.e., in some stromatolite samples (Cs12, $\mathrm{C} 32, \mathrm{Cs} 32)$ as well as in upstream sediments collected in both February 2000 (S2F00, S30F00) and January 2002 (S0J02, S2J02, S12J02) (Figure 7; Table 1). Tooeleite exhibits similar morphology in the B5 bioassay sample, although the platy crystallites are smaller than those in natural samples. SEM examination of the As(III)-rich samples where tooeleite is not abundant ( $\leq 20$ wt $\%$ in C12; Figures 2 and 7; Table 1) shows that the am-As(III)Fe(III)-Ox appears as a compact, homogeneous material. In the C12 sample, tooeleite surrounds an am-As(III)Fe(III)-Ox inner-core (Figure 8). One may infer from these SEM observations that tooeleite forms 

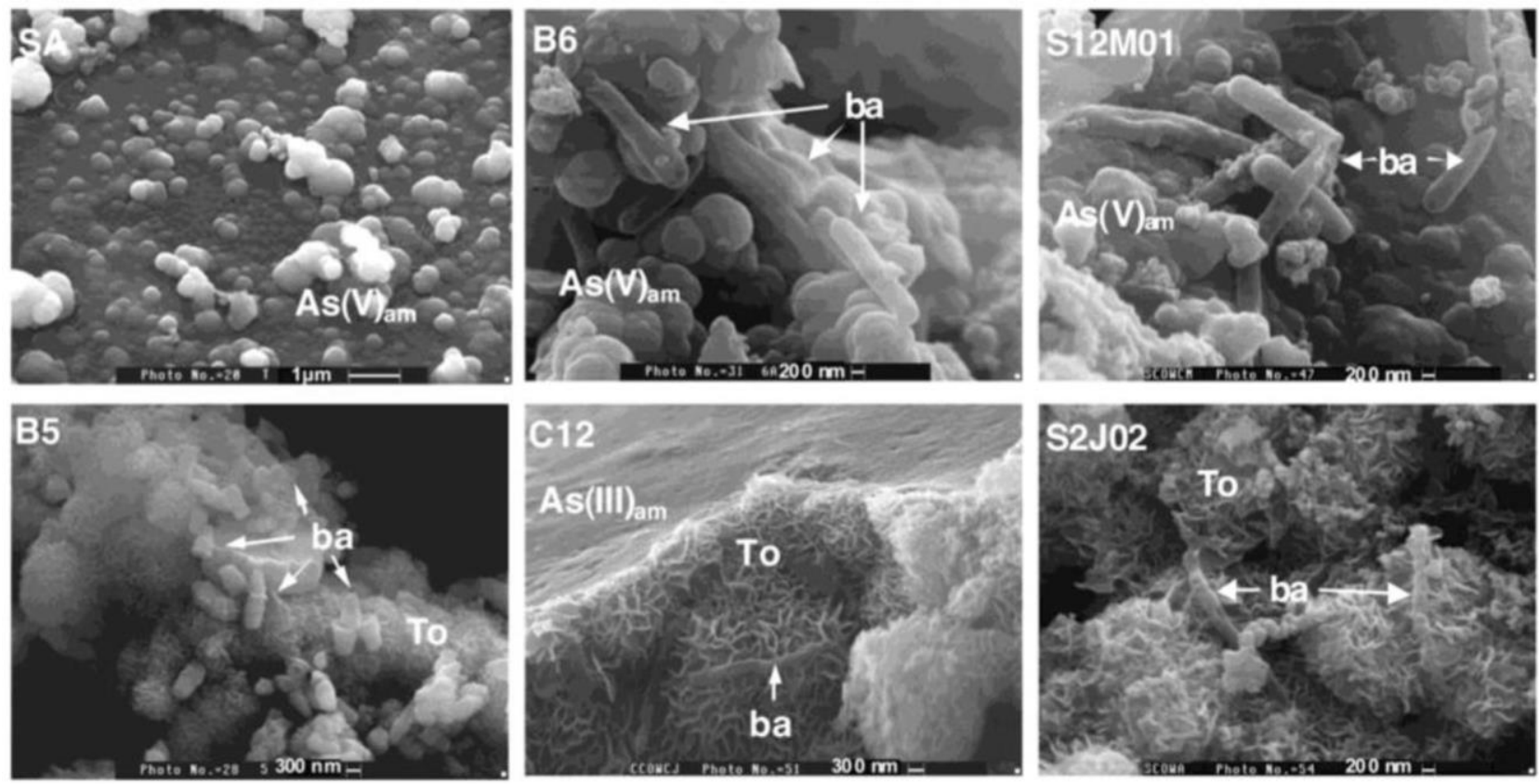

FIGURE 8. SEM images (secondary electrons) of representative field samples (C12: stromatolite, S12M01: May 2001 sediment, S2J02: January 2002 sediment) and bioassay samples (SA: abiotic, B5: Acidithiobacillus ferrooxidans; and B6: undetermined phyllum). The am-As(V)Fe(III)-0x ( $\mathrm{As}(\mathrm{V})$ am $)$ appears as small coalescing spherules of a few hundreds of nanometers in diameter (see SA, B6, and S12M01). Tooeleite (To) exhibits a reticulated structure consisting of nanosized platy crystallites (see B5, C12, S2J02). The am-As(III)Fe(III)-0x (As(III) am) appears as a compact homogeneous material (see C12). Note the presence of bacterial cells (ba) with various morphologies.

after am-As(III)Fe(III)-Ox, perhaps upon reacting with interstitial water within the sediment (C12 in Figure 8).

As(V) Samples. All sediments collected in May 2001 (S2M01, S12M01, S32M01) and downstream sediments collected in February 2000 (S32F00, S38F00) as well as most of the bioassay samples (SA, B1, B2, B3, B4, and B6) have a yellow-white color and are essentially XRD-amorphous (Figures 1 and 2). XANES data indicated that they are all dominated by As(V) (Figures 3 and 7, Table 1). XRD patterns of these samples exhibit three main broad bands around 17.0, 3.1, and $1.6 \AA$ (Figure 3). These features differ from those of poorly ordered or nanocrystalline ferric oxyhydroxides, such as 2- and 6-lines ferrihydrite or schwertmannite $(14,29)$. In contrast, the bands at 3.1 and $1.6 \AA$ are similar to those observed for mixed $\mathrm{As}(\mathrm{V})$ - $\mathrm{Fe}$ (III) precipitates with high As/Fe-ratios occurring in some As-rich AMD (14). Under SEM examination, the am-As(V)Fe(III)-Ox phase appears as small coalescing spherules of various diameter $(200-500 \mathrm{~nm})$ as illustrated in Figure 8 for the SA, B6, and S12M01 samples.

Spatial and Seasonal Variations of As Speciation. In the Carnoulès AMD, the nature of the neoformed mineral phases and the oxidation state of As in these solids vary from up to downstream and also as a function of season (Figure 4). Quantitative As speciation derived from XANES spectra of the field solid samples indicate that $\mathrm{As}(\mathrm{V})$ dominates in the dry season sediments, while As(III) dominates in the wet season sediments from the upstream zone (up to $30 \mathrm{~m}$ downstream from the spring) and in stromatolites (Table 1 , Figure 7).

In February 2000, the As oxidation state in suspended sediments varied from $100 \% \mathrm{As}(\mathrm{III})$ upstream to more than $95 \% \mathrm{As}(\mathrm{V})$ downstream. The same trend is observed in January 2002 , but the proportion of $\mathrm{As}(\mathrm{V})$ reaches only $57 \%$ in downstream sediments. At the same period, As remains only as As(III) in $0.45 \mu \mathrm{m}$ filtered water samples collected at the site (Table 3, Supporting Information).

In May 2001, As only occurs as As(V) in the suspended sediments whatever their sampling position along the
Carnoulès AMD (Figures 4 and 7), but As is still present mainly as As(III) in filtered water (Table 3, Supporting Information).

According to these observations, it is remarkable that downstream sediments, whatever their sampling period (S32F00, S38F00, S38M01, S38J02), exhibit more than 55\% As(V) (Figures 4 and 7), even though As(III) always dominates in the corresponding $0.45 \mu \mathrm{m}$ filtered water.

Such differences between As oxidation state in the solid and aqueous phases suggest that As oxidation state in the sediments is not directly controlled by its speciation in solution in the Carnoulès AMD. The presence of $\mathrm{As}(\mathrm{V})$ in the sediments may result either from the coprecipitation of As(V) with Fe(III) immediately after As(III) oxidizes in solution or from the coprecipitation of As(III) with $\mathrm{Fe}$ (III) followed by oxidation of As(III) in the suspended solids upon aging in water. The two processes could also act simultaneously in the Carnoulès AMD.

As Speciation in Bioassay Samples. Bioassays emphasized the role of isolated bacterial strains in catalyzing As(III) to $\mathrm{As}(\mathrm{V})$ and/or $\mathrm{Fe}$ (II) to $\mathrm{Fe}$ (III) oxidation reactions and in governing the structure of As-Fe precipitates forming at Carnoulès. XANES spectra of bioassay precipitates are displayed in Figure 5, and quantitative As speciation is summarized in Figure 7. More detailed results of these experiments are reported in Table 2. They show that both As(III) and $\mathrm{As}(\mathrm{V})$ may coprecipitate with Fe(III) produced by the oxidation of dissolved $\mathrm{Fe}$ (II) and that As removal from solution increases when the $\mathrm{Fe}$ (II) oxidation reaction and the subsequent precipitation of $\mathrm{Fe}$ (III) are catalyzed by bacteria. Two types of behavior can be distinguished as a function of As oxidation state in the solid samples: (i) SA (abiotic) as well as B1, B2, B3, B4, and B6 experiments yielded similar precipitates consisting mostly of $\mathrm{As}(\mathrm{V})$ ferric hydroxide (Figures 3, 5, and 7), although the amount of precipitate formed drastically varied among these experiments, as indicated by the percentages of Fe-removal from solution (Table 2). Analysis of the control sample (SA) indicates that abiotic oxidation of As did not exceed $20 \%$ of total As under our experimental conditions ( $150 \mathrm{~h}$ aging). The $\mathrm{B} 1 \mathrm{strain}$ did 
TABLE 2. Summary of Bioassays' Results ${ }^{a}$

\begin{tabular}{|c|c|c|c|c|}
\hline sample & $\underset{\text { removal \% }}{\text { As }}$ & $\underset{\text { removal \% }}{\mathrm{Fe}}$ & $\begin{array}{l}\text { \% As(III): } \\
\text { 2As solid }\end{array}$ & $\begin{array}{c}\% \operatorname{As}(\text { III): } \\
\text { 2As dissolved }\end{array}$ \\
\hline SA & $21 \pm 2$ & $4 \pm 2$ & $<5$ & $>95$ \\
\hline $\mathrm{B} 1(\mathrm{Tm})$ & $22 \pm 2$ & $5 \pm 2$ & $<5$ & $>95$ \\
\hline B2 (Tm) & $25 \pm 2$ & $5 \pm 2$ & $<5$ & $<5$ \\
\hline B3 (Tm) & $38 \pm 3$ & $4 \pm 2$ & $<5$ & $<5$ \\
\hline B6 (nd) & $87 \pm 4$ & $18 \pm 2$ & $<5$ & $<5$ \\
\hline B4 (Af) & $23 \pm 2$ & $5 \pm 2$ & $10 \pm 2$ & $>95$ \\
\hline B5 (Af) & $36 \pm 3$ & $11 \pm 2$ & $80 \pm 2$ & $>95$ \\
\hline
\end{tabular}

Isolated bacterial strains (B1-B6) were incubated for 7 days in sterilized Carnoulès water sampled in June 2001 and containing 3.45 $\mathrm{mM} \mathrm{As}$, as As(III), and $33.5 \mathrm{mM} \mathrm{Fe}$, as Fe(II). Abiotic (SA), Thiomonas (Tm), Acidithiobacillus ferrooxidans (Af), undetermined phyllum (nd).

not have a significant effect on either Fe(II) or As(III) oxidation reactions, the results of the $\mathrm{B} 1$ experiment being similar to that of the abiotic (SA) experiment (Table 2), i.e., low As and Fe removal. Almost the same conclusion can be drawn for the B4 strain, although the neo-formed solid-phase incorporated a small amount of As(III) (Table 2). The B2 and B3 Thiomonas strains were both able to oxidize all the dissolved As(III) in our experimental conditions but did not significantly accelerate As removal (Table 2), likely because these strains did not accelerate the oxidation of $\mathrm{Fe}$ (II) and the subsequent coprecipitation of $\mathrm{As}(\mathrm{V})$ with $\mathrm{Fe}(\mathrm{III})$. The $\mathrm{B} 6$ population catalyzed the oxidation of both Fe(II) and As(III) in solution and thus accelerated the formation of am-As(V)Fe(III)-Ox (Table 2). (ii) B5 data indicate that this strain catalyzed the oxidation of $\mathrm{Fe}$ (II) and not that of As(III) and thus favored the formation of nanocrystalline tooeleite associated with am-As(III)Fe(III)-Ox (Figures 5 and 7). The ability of the B5 strain to oxidize $\mathrm{Fe}$ (II), which is shown by the relatively high Fe removal during the B5 experiment (Table 2), is consistent with its Acidithiobacillus ferrooxidans genotype.

\section{Discussion}

Tooeleite and XRD-Amorphous Mixed As(III)-Fe(III) OxyHydroxides. The coprecipitation of large amounts of As(III) with $\mathrm{Fe}$ (III) in the Carnoulès AMD is unusual with respect to recent studies of As speciation in AMD where As(V) commonly dominates over As(III) in solid phases $(14,15$, 20). The presence of As(III)-rich precipitates could be related to the exceptionally high concentrations of dissolved As(III) (up to $250 \mathrm{mg} / \mathrm{L}$ ) in the acidic spring of the Carnoulès AMD. However, even though a high concentration of dissolved As(III) may be required to form tooeleite and am-As(III)$\mathrm{Fe}$ (III)-Ox, bacteria likely play a key role in the formation of these mineral phases at Carnoulès. This assumption is supported by the absence of As(III)-bearing solids in the abiotic experiment (SA). Indeed, tooeleite, associated with am- $\mathrm{As}$ (III)Fe(III)-Ox, was only found in the B5 precipitate, while all other experiments, including the abiotic one, lead exclusively to the formation of am-As(V)Fe(III)-Ox. The B4 Acidithiobacillus ferrooxidans strain studied did not lead to tooeleite formation, suggesting a phenotypic peculiarity of B5. These results suggest that the formation of tooeleite and am-As(III)Fe(III)-Ox observed especially in the wet season at Carnoulès, is caused by the activity of bacterial populations able to oxidize Fe(II) rapidly and unable to oxidize As(III), similar to the B5 Acidithiobacillus ferrooxidans strain. However, no direct relationship can yet be established between the morphology of the bacteria associated with tooeleite in the Carnoulès AMD and the morphology of the B5 strain in bioassays (Figure 8). This discrepancy suggests that other factors, including other microorganisms not yet identified, could promote the formation of tooeleite at Carnoulès.
XRD-Amorphous Mixed As(V)-Fe(III) Oxy-Hydroxides. According to the results of our bioassay experiments, the formation of am-As(V)Fe(III)-Ox might involve both abiotic and biotic processes. In the abiotic experiment (SA sample) the formation of am- $\mathrm{As}(\mathrm{V}) \mathrm{Fe}$ (III)-Ox results from the oxidation of a small fraction of dissolved $\mathrm{Fe}$ (II) and from the oxidation of about $20 \%$ of the total As(III). Oxidation of As(III) in this experiment could be related to the catalytic role of $\mathrm{Fe}$ (II) in Fenton type reactions, as recently reported ref 30 . Nevertheless, As removal $(20 \%)$ was relatively low in this blank experiment. Although Thiomonas strains B2 and B3 catalyze the oxidation of As(III) in solution, they do not accelerate the formation of am-As(V)Fe(III)-Ox, with respect to the abiotic experiment, because they do not facilitate $\mathrm{Fe}$ (II) oxidation. Consequently, B1 and B2 experiments yielded similar As removal than the abiotic experiment. In contrast, the unidentified B6 population, which is able to catalyze the oxidation of $\mathrm{Fe}$ (II) together with that of As(III), drastically accelerates the formation of am- $\mathrm{As}(\mathrm{V}) \mathrm{Fe}(\mathrm{III})-\mathrm{Ox}$ and in turn yields the best As removal (85\%).

Analyses of field samples revealed that As(III)-mineral phases are almost absent in the dry season and regularly disappear from upstream to downstream, in the wet season (Figure 7). The disappearance of As(III)-mineral phases coincides with the systematic formation of am-As(V)Fe(III)Ox with pale-yellow color. Such changes in the oxidation rate of arsenic in the Carnoulès AMD are likely related to spatial and seasonal changes in bacterial activity. The origin of these changes is not yet understood; they could be caused for instance by temperature or oxygenation changes or by stressing conditions related to elevated As(III) concentrations (Table 3, Supporting Information). In the dry season whatever the sampling point, and downstream whatever the season, the systematic precipitation of am-As(V)Fe(III)-Ox may be promoted by the activity of bacterial populations, able to oxidize both As(III) and Fe(II), as B6, or by the synergic activity of specific Thiomonas strains able to oxidize As(III) and of specific Acidithiobacillus ferrooxidans strains able to oxidize $\mathrm{Fe}$ (II). An abiotic contribution to the formation of amAs(V)Fe(III)-Ox can however not be excluded, since $20 \%$ of the initial As(III) was oxidized in our abiotic experiment. Further microbiological studies are in progress in order to confirm and explain these spatial and seasonal variations of bacterial activity at the Carnoulès site.

\section{Acknowledgments}

This paper is dedicated to Prof. Philippe Ildefonse who was the leader of our environmental research group in Paris and who initiated this mineralogy work at the LMCP. The authors are indebted to Prof. Fabien Cesbron who provided a Utah tooeleite sample from his personal collection. Dr. Stephanie Belin and Dr. Valerie Briois and the technical staff of LURE Synchrotron Laboratory are kindly acknowledged for tuning the D44 beamline during XANES experiments. The synchrotron XRD pattern of tooeleite was recorded by Erick Elkaim at DW22 LURE. Dr. Sefan Borensztajn and Prof. Luc Beaunier are especially acknowledged for their help in SEM microphotography and analyses. This work is supported by the French PEVS-CNRS program 2001-2003 (\#00N55/0093) and the European Program PIRAMID (Passive In-situ Remediation of Acid Mine Industrial Drainage) of the $V^{\text {th }}$ Framework Program (Contract EVK1-CT-1999-000021). This is IPGP contribution \#1879.

\section{Supporting Information Available}

Water chemistry data on the Carnoulès AMD sampled in February 2001, May 2001, and January 2002 (Table 3). This material is available free of charge via the Internet at http:// pubs.acs.org. 


\section{Literature Cited}

(1) Nordstrom, D. K.; Alpers, C. N. The environmental geochemistry of mineral deposits. In Reviews in Economic Geology, Plumlee, G. S., Logsdon, M. J., Eds.; Society of Economic Geologists Inc.: Littleton, CO, 1999; Vol. 6A.

(2) Bigham, J. M.; Schwertmann, U.; Carlson, L. Catena Suppl. 1992, $21,219-232$.

(3) Jambor, J. L.; Blowes, D. W. The Environmental geochemistry of sulphide mine-wastes. Short Course Handbook: Mineralogical Association of Canada: Nepean, Ontario, 1994; Vol. 22.

(4) Brown, G. E., Jr.; Foster, A.; Ostergren, J. D. Proc. Natl. Acad. Sci. U.S.A. 1999, 96, 3388-3395.

(5) Brown, G. E., Jr. Science 2001, 294, 67-70.

(6) Leblanc, M.; Achard, B. Appl. Geochem. 1996, 11, 541-554.

(7) Elbaz-Poulichet, F.; Dupuy, C.; Cruzado, A.; Velasquez, Z.; Achterberg, E. Water Res. 2000, 34, 3222-3230.

(8) Lee, G.; Bigham, J. M.; Faure, G. Appl. Geochem. 2002, 17, 569581.

(9) Pichler, T.; Veizer, J.; Hall, G. E. Environ. Sci. Technol. 1999, 33 , 1373-1378.

(10) Wilkie, J. A.; Hering, J. G. Environ. Sci. Technol. 1998, 32, 657662 .

(11) Morin, G.; Lecocq, D.; Juillot, F.; Ildefonse, Ph.; Calas, G. Bull. Soc. Géol. Fr. 2002, 173, 281-291.

(12) Bigham, J. M.; Schwertmann, U.; Traina, S. J.; Winland, R. L.; Wolf, M. Geochim. Cosmochim. Acta 1996, 60, 2111-2121.

(13) Savage, K. S.; Tingle, T. N.; O'Day, P. A.; Waychunas, G. A.; Bird, D. K. Appl. Geochem. 2000, 15, 1219-1244.

(14) Carlson, L.; Bigham, J. M.; Schwertmann, U.; Kyek, A.; Wagner, F. Environ. Sci. Technol. 2002, 36, 1712-1719.

(15) Foster, A. L.; Brown, G. E., Jr.; Tingle, T. N.; Parks, G. A. Am. Mineral. 1998, 83, 553-568.
(16) Langner, H. W.; Jackson, C. R.; McDermott, T. R.; Inskeep, W. Environ. Sci. Technol. 2001 35, 3302-3309.

(17) Gihring, T. M.; Druschel, G. K.; McCleskey, R. B.; Hamers, R. J.; Banfield, J. F. Environ. Sci. Technol. 2001, 35, 3857-3862.

(18) Salmassi, T. M.: Venkateswaren, K.; Masataka, S.; Nealson, K. H.; Newman D.; Hering, J. G. Geomicrobiol. J. 2002, 19, 53-66.

(19) Wakao, N.; Koyatsu, H.; Komai, Y.; Shimokawara, H.; Sakurai, Y.; Shiota, H. Geomicrobiol. J. 1988, 6, 11-24.

(20) Zänker, H.; Moll, H.; Richter, W.; Brendler, V.; Hennig, C.; Reich, T.; Kluge, A.; Hüttig, G. Appl. Geochem. 2002, 17, 633-648.

(21) Leblanc, M.; Casiot, C.; Elbaz-Poulichet, F.; Personné, J. C. Geol. Soc. London Special publication "Mine water hydrogeology and geochemistry" 2002, 198, 267-274.

(22) Michard, G.; Faucherre, J. Chem. Geol. 1970, 6, 63-84.

(23) Reasoner, D. J.; Geldreich, E. E. Appl. Environ. Microbiol. 1985. $49,1-7$.

(24) Schrader, J. A.; Holmes, D. S. J. Bacteriol. 1988, 170, 3915-3923.

(25) Cesbron, F. P.; Williams, S. A. Mineral. Magn. 1992, 56, 71-73.

(26) Rodier, J. L'analyse de l'eau, Dunod: Paris, 1996; pp 214-352.

(27) Branch, S.; Corns, W.; Ebdon, L.; Hill, S.; O'Neill, P. J. Anal. At. Spectrosc. 1991, 6, 155-158.

(28) Kaskur, Z. Appl. Crystallogr. 2000, 33, 87-94.

(29) Schwertmann, U.; Cornell, R. M. Iron oxides in the laboratory; Verlag Chemie: Weinheim, 1991; p 137.

(30) Hugh, S. J.; Canonica, L.; Wegelin, M.; Gechter, D.; Von Gunten, U. Environ. Sci. Technol. 2001, 35, 2114-2121.

Received for review March 29, 2002. Revised manuscript received January 6, 2003. Accepted January 15, 2003.

ES025688P 